\title{
Information Accessibility and Utilization: The Panacea to Job Performance and Productivity of Academic Staffln the Faculties of Agricultural Sciences: A Case Study
}

\author{
Familusi E. B., N. A. Ajayi \\ University Library, Ekiti-State University, Ado-Ekiti, Ekiti-State, Nigeria \\ Email address: \\ familusiezekiel@gmail.com (Familusi E. B.), nathajayi@yahoo.com.uk (N. A. Ajayi)
}

\section{To cite this article:}

Familusi E. B., N. A. Ajayi. Information Accessibility and Utilization: The Panacea to Job Performance and Productivity of Academic StaffIn the Faculties of Agricultural Sciences: A Case Study. International Journal of Intelligent Information Systems.

Vol. 4, No. 6, 2015, pp. 95-100. doi: 10.11648/j.ijiis.20150406.11

\begin{abstract}
This study probes into accessibility and utilization of information resources by academic staff in the Faculties of Agricultural Sciences of selected universities in the Southwest, Nigeria. The objectives of this study were to determine the level of information access and utilization, identify the factors responsible for low productivity, and investigate challenges confronting information access and utilization. This study adopted a descriptive survey design to describe information accessibility and utilization. The researchers made use of questionnaires which were administered among two hundred (200) out of which 182 (91.9percent) were found useful Academic Staff randomly selected from Faculties of Agricultural Sciences. The study found that majority of the respondents (51.3\%), frequently used virtually all the resources, and e-resources most especially internet/CD-ROM and databases were perceived to be most accessible of all the resources (index of 3.9), followed by textbook (index of 3.7), while the least accessible information resources was electronic board. Low productivity was caused by high no of students assigned to each academic staff for teaching and supervision (11.8\%) followed by lack of internet facilities (11.1\%), while inadequate workspace did not significantly contribute to their low productivity $(6 \%)$. Challenges faced by academic staff in information resources accessibility and utilization include epileptic power supply, poor ICT maintenance, poor funding, internet connectivity and, computer illiteracy. It was recommended that the Federal government of Nigeria should collaborate with the universities administrators to accord priority to Nigerian Universities in financial commitment, provision of regular supply of electricity in campuses and others to enhance high productivity of the university academic staff.
\end{abstract}

Keywords: Information Resources, E-Resources, ICTs, Accessibility, Utilization, Job Performance, Productivity, Academic Staff, Agricultural Sciences

\section{Introduction}

Information has become a critical economic resource globally, even in the most remote villages. People including illiterates cannot do but need information for their day to day livelihood. Amogu, (2010) asserted that, information is the processed data that could be converted into more meaningful format which is the end product of data processing. Information accessibility and utilization has multiplying effects on individual's positive tendencies. Information access and utilization will make people to understand their environment better, learn new skills and be able to make well informed decisions about their lives. The onus rest on the university management in collaborating with Librarians to use professional's skills to facilitate access to useful and relevant information, which will enable people to develop their full potentials and live productive lives. It is therefore, imperative that libraries must provide relevant literature to academic communities for the realization of research and academic excellence.

With the information explosion being experienced all over the world and the demand for quick and relevant information by library users, librarians are constantly challenged to provide accurate, complete and timely information for research and development. Information access is the gateway to information utilization and consequently high productivity is easily achievable. Aina, et.al. (2010) argued that, the evolving information and knowledge-based economy has resulted in a climate of transition and change especially in 
academic libraries around the world, including Nigeria as universities, polytechnics and colleges make the transformation to higher institutions. Adebowale(2007) observed that, globally education is seen as the bedrock of a nation; hence its quality should be well enhanced and ascertained. However, Ileboya(2010) emphasized that, productivity is considered as key source of economic growth and competiveness and as such, it is a basic statistical information for many international comparisons and country performance assessment.

\subsection{Literature Review}

Information had become an all-embracing factor with which man can effectively cope with the challenges of the present dynamic world posed daily by science and technology as a result of industrial revolution cutting across all sphere of human endeavour. Popoola(2009)viewed information as a critical economic resource when utilized is capable of increasing the knowledge state of an individual in taking the right decision. Aina(2004)opined that information is a process which involves transmitting information from the source to a recipient. It is knowledge when is performing the role of imparting knowledge to an individual, where it reduces uncertainty.

Lawal and Taofeek(2009)identified information in the new world order that there is every reason to believe that information has become ubiquitous and therefore can be obtained at any time, and in any location no matter the distance, as long as necessary infrastructural devices and the skill to retrieve information from global networks are available. Information access and utilization play dominant roles in teaching, learning and research process. Popoola (2009) asserted that information enables the user to take the right decision which positively affects productivity. Also, organizations are made up of people working together to achieve common goals. Edom(2010) posited that, beside teaching, learning, and research, ICTs are also used in the performance of other tasks in the universities. Edom(2010) cited Ebijuwa (2005) that ICT could be used for administration, information management, teaching and learning, research and national networking, library and information services.

Nwokedi (2007) opined that the internet has broken down the barriers of communication access from anywhere in the world. It is fast, reliable, and does not have restrictions on content formats. Tibenderana (2010) also asserted that, with the introduction of new technologies in the last quarter of the past century such as ICT and other services can be automated such that end users can access them by means of networked computers through the web (internet/intranet) or a Local Area Network (LAN). Convincingly, access to information is a motivator that naturally encourages the three domains of learning and teaching to maximally utilize information. Abdullahi and Haeuna (2008) argued that, Librarians as information managers should be up to the task by being familiar with this digital era so as to give the clients the services required. Ogundeji, et.al.(2009) also stressed the importance of the Internet on learning, research and teaching process. Danjuma, (2011) opined that, information utilization goes beyond research and service delivery, and the users outlook as well. The advent of Information Communication Technology (ICT) has brought along stress-free academic and research delivery.

The impact of ICT on Nigerian universities teaching and learning processes are enormous. Information access, dissemination, utilization, teaching and learning processes passes through other ICT mediums unlike the verbal and manual delivery of lectures. Such media include the use of computers and its software, overhead projectors, laptops, PowerPoint lecture delivery, teleconferencing -mail messages, facsimile, Hotmail, newsgroup, etc. Kumar et.al (2011) advocated that the effect of computer simulation supported learning on the conceptual understanding of elementary and secondary teachers were presented. Khan(2011) corroborated Kumar et.al.(1997) that Technological Pedagogical Content Knowledge (TPACK) is an emerging theoretical framework on teaching that articulates a tri-partite relationship among teacher's knowledge, technology pedagogy, and content. Aina (2004) in her own view submitted that modern technologies in libraries create a new forum for global information access. Rajput and Gautam (2010) stated that modern society is characterized by an increasing need for specialized information in various fields of activities for the performance of their day to day functions as well as research consultancy services to handle the vast amount of information and for providing faster, accurate precise, efficient and effective information dissemination. Bwalya(2013) advanced the significance of access and utilization of information that most of the contemporary socio-economic value chains can be amassed by appropriate and efficient utilization of ICTs.

Oyekunleand Majebi (2013) upheld Bwalya(2013)that, rapid development of the World Wide Web offers universities unparalleled possibilities for communication with internal and external audiences. Nigerian universities, like those in developed countries, have more and more adopted the Internet as a communication and information tool. Oyekunle et.al.. (2011) agreed that, the birth, creation, planning, implementation, appraisal and amendment of the universities' curriculum is now much more universally uniform, accessible and easily utilized with the advent of the Internet. Much more could be archived in job performance and productivity. The ICT has finally removed the stress, time wastage, passive participation of the teacher-student interactions in lectures and enhanced productivity.

\subsection{Statement of the Problem}

Information access and utilization is very significant to the rapid economic transformation of any nation in the world. It is very imperative that uninterrupted access and utilization of information in our citadels of learning is an indicator to rapid production and growth of human and material resources. Continuous access and utilization of information is a correlate of high level of productivity. Accessibility and 
utilization of information by academics in higher institutions will go a long way to make teaching and learning process easier, meaningful, and effective, result oriented and productive. Availability of the relevant information and access to internet deserve utmost attention by the university management. Accessibility to exploit the seamless information via the internet is lacking in most universities which can lead to low productivity. This study is set to investigate and determine the level of accessibility and the utilization of information by the academic staff of the Faculties of Agricultural Sciences in selected universities in Nigeria.

\subsection{Objectives of the Study}

The objectives of this study are to:

i. Find out the level of accessibility and the utilization of information by the lecturers in the Faculties of Agricultural Sciences.

ii. Identify the factors responsible for low productivity if any

iii. Investigate challenges confronting accessibility and utilization of information by the university lecturers, and recommend possible solutions.

iv. Suggest possible solutions to identified problem

\subsection{Research Questions}

i. What is the level of accessibility of information resources?

ii. What is the frequency of use of information resources?

iii. What are the challenges confronting accessibility and utilization of information?

iv. What are the factors responsible for low productivity?

\section{Methodology}

In carrying out the study, the advice of Quinsee and McDonald (1991) and Obiagwu (1992) that the views of academic staff are the most revealing on issues like this in academic libraries was utilized. Using a structured questionnaire the information elicited from the respondents included accessibility of information resources, use of available resources, challenges of information availability and factors responsible for low productivity. The data also included the demographic background and academic status.

A total of 200 academic staff randomly selected from 5 Faculties of Agriculture in Federal, State and private universities who were users of their University Libraries were sampled, using a systematic random sampling technique to distribute the questionnaire. Focus group discussions (FGD) were also conducted to clarify some of the perceptions that were indicated in the responses. A total of 198 completed questionnaires were returned of which 182 were found useful. Of the 182 respondents, considering the gender of the respondents 99 (54.5 percent) were male, while 83(45.5 percent) were female. Also, the academic qualifications of the respondents revealed that, $83(45.5$ percent) were $\mathrm{PhD}$ holders, 62(34.1percent) holds Masters Degree while the remaining $37(20.3$ percent $)$ were First degree holders. 25(13.6 percent) were Professors, 33(18.2percent) were Readers, 59(32.4 percent) were Senior Lecturers and 65(35,7percent) were Lecturer 1 and below.

\section{Results and Discussion}

\subsection{Use of Information Resources}

The respondents were asked to indicate the frequency use of Information Resources. They were to choose from options given like $\{\mathrm{MF}\}$ most frequently, $\{\mathrm{F}\}$ frequently, $\{\mathrm{LF}\}$ less frequently, and $\{\mathrm{NF}\}$ not frequently. Fig.1. below shows that fifty one $(51.3 \%)$ percent of them frequently used virtually all the resources available to them. Almost thirty three $\{32.9 \%\}$ percent less frequently used the resources. Just 6.9 percent did not use any of the resources meaning that they were not library users. From the above research result, information utilization is the key to effective learning, teaching, and research delivery. Popoola $\{2009\}$ opined that, information utilization increases the knowledge state of an individual which enables him to solve a problem and take the right decision. Also, Hussain and Kumar \{2013\} suggested that there should be no restriction in the utilization of information resources including photocopying from remains encyclopedias because it is beyond financial reach of scholars/ researchers.

\subsection{Use of Electronic Resources}

The respondents were asked explicitly about their use of eresources and printed resources and how they felt this had changed the relationship between the use of library resources and the support of research. Researchers saw many conveniences of electronic resources. There was a perception, true or not that almost all resources were available "It has certainly affected the way I work, simply by being able to access libraries". "I get a lot of empirical data from the Internet".

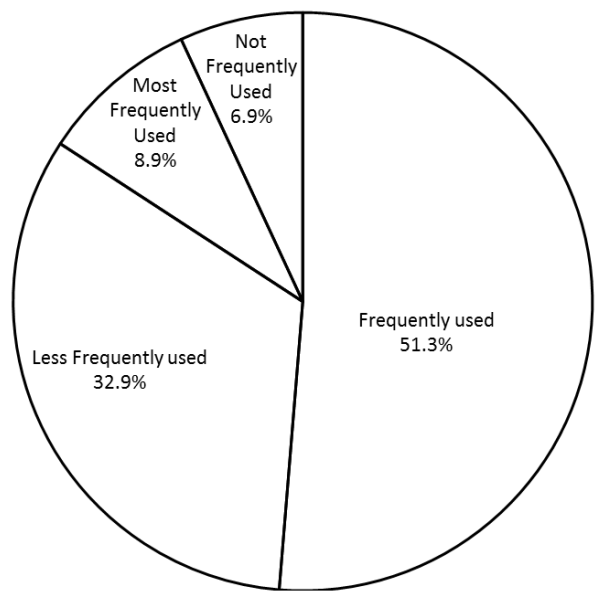

Fig. 1. Use of Information Resources. 


\subsection{Accessibility to Information Resources}

The respondents were asked how accessible are the information resources listed below in table 1. The table shows that 3.9 index indicated their accessibility to the Internet/ Database .Access to textbooks was 3.7 and 3.5 index for references sources. The least of the resources is electronic board with 2.5. Ode and Ape (2013\} stated that, information literacy sometimes referred to as information competency as the ability to access, evaluate, organize and use information from a variety of sources. In the same vein, Nwokedi (2007) corroborated that, the Internet has broken down barriers of communication access from anywhere in the world. It can be inferred that lecturers had access to most resources available to them.

Table 1. Accessibility to Information Resources.

\begin{tabular}{|c|c|c|c|c|c|c|}
\hline Information Resources & Very Easily Accessible & Easily Accessible & Occasionally Accessible & Not Accessible & Total & Index \\
\hline & $\{5\}$ & $\{4\}$ & $\{3\}$ & $\{2\}$ & & \\
\hline Internet/CDRom Databases & 370 & 340 & - & 46 & 756 & 3.9 \\
\hline Textbook & 250 & 336 & 75 & 46 & 707 & 3.7 \\
\hline Reference Materials & 45 & 408 & 213 & - & 666 & 3.5 \\
\hline Abstracts & - & 500 & 102 & 46 & 648 & 3.4 \\
\hline Statistical Publications & - & 500 & 102 & 46 & 648 & 3.4 \\
\hline Conferences Proceedings & - & 420 & 195 & 24 & 639 & 3.3 \\
\hline Journals & - & 336 & 225 & 46 & 607 & 3.2 \\
\hline These/ Dissertation & - & 400 & 87 & 106 & 593 & 3.1 \\
\hline Government Document & - & 216 & 348 & 24 & 538 & 3.1 \\
\hline Newspapers/Magazines & - & 220 & 225 & 104 & 549 & 2.9 \\
\hline Project/Electronic Board & - & 120 & 147 & 206 & 473 & 2.5 \\
\hline
\end{tabular}

\subsection{Factors Responsible for Low Productivity}

This study was out to identify the factors responsible for academic staff low productivity. Table 2.below revealed that high number of students assigned to an academic staff were the bane of low productivity $(11.8 \%)$, in the same vein, lack of internet facilities (11.1\%) was the cause of low productivity. The least cited cause of low productivity was inadequate workstations (6.6\%). It is true that in most faculties, lecturers shared offices. This becomes complicated with the existing poor working environment in terms of inadequate offices accommodation, furniture and insufficient working materials. Akinyemi and Bassey (2012)emphasized that students enrolment in Nigerian public universities yearly was outrageous by outnumber the available spaces, infrastructure and the few lecturers were overstretched with teaching activities.

Table 2. Factors Responsible for Low Productivity.

\begin{tabular}{lll}
\hline Causes of Low Productivity & Responses & Percentage\% \\
\hline High number of Students Assigned to & 176 & 11.8 \\
lecturers & 166 & 11.1 \\
Lack of internet facilities & 150 & 10.1 \\
Inadequate space & 140 & 9.4 \\
Computer illiteracy & 137 & 9.2 \\
Poor maintenance of ICT facilities & 136 & 9.1 \\
Poor library services & 136 & 9.1 \\
Low bandwidth & 133 & 8.9 \\
Obsolete print materials & 166 & 7.8 \\
Expensive costs of internet connection & 104 & 7.0 \\
Epileptic power supply & 98 & 6 \\
Inadequate workstation & & \\
\hline
\end{tabular}

\subsection{Challenges Confronting Accessibility of Information}

The respondents were requested to prioritize the challenges faced in the utilization of information resources. Fig. 2.below shows that twenty-two (22.1\%) percent indicated that poor funding of the universities was their major constraints, while epileptic power supply $(16.6 \%)$ and inadequate workstation and space respectively ranked second. The least of the challenges was computer illiteracy (5.1\%). Akinyemi and Bassey (2012) lamented that higher institutions have experienced increase in enrolments; therefore Nigeria is faced with the challenges of high demand for admission leading to escalated enrolment, insufficient funds and physical facilities. In addition, Kpolovie and Obilor (2013) reported that Nigeria's annual budgetary allocation to education was $(5.57 \%)$ which was significantly lower than the UNESCO recommended minimum of $26 \%$ for developing countries.

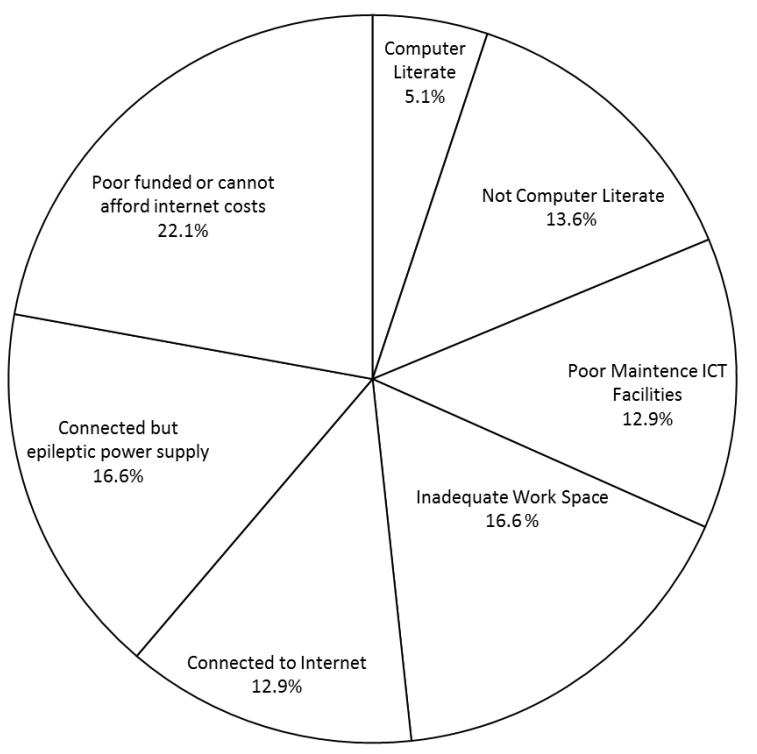

Fig. 2. Challenges.

3.6. Summary 
The study reveals that e-resources remain the most accessible information resource while books and journals, were also considered moderately. One may identify citations in indexes, but may not have access to the sources containing the relevant articles. The more accessible information sources are, the more likely they are to be used. One reason why library-held resources (electronic and print) are of importance to the research-teaching relationship is that they are both the tools and the product of scholarship and enquiry. As one of the Zamdock(2002) put it every book you pick up, every journal article and resources you look at is based on somebody's research. Dictionaries were the most frequently reference resources used followed by Journals, Abstracts and Textbooks. This is corroborated by Korobili, et. al. (n.d.) who conducted a research on the use of library resources by the members of the faculty of a higher educational institute in Thessaloniki, Greece found that the great majority of the faculties of TEI uses printed sources more than e-sources, but they also used e-sources quite frequently. There were many challenges confronting information accessibility, the greatest challenge militating against easy access to information was the epileptic power supply in all the universities surveyed in this study, poor maintenance, inadequate work stations and space were also cited. It was equally revealed that the problem of easy access to information were peculiar to all the universities, this was corroborated by Oyewusi, \& Oyeboade (2009), Ugah (2007) \& Ogunsola (2004).

Information accessibility and utilization by academic staff of Agricultural Sciences in the selected universities leaves much to be desired because the respondents' access to the Internet accelerate the rate and success of learning, teaching and research in higher institutions of learning. Ofori-Dwumfuo\&Ado (2012) Hussain\& Kumar (2013) emphasized that the Internet services must be improved to help access information and added that information is acquired, processed and disseminated through the university library and there should no restriction in the utilization of information resources. Also, student's overpopulation admission syndrome in tertiary institutions with few academic staff, lack of ICT facilities due to poor funding and maintenance culture were contributory factors. It was not therefore a surprised that Ayo-Shonibare (2011) stated that the problem of funding and financing of our universities in Nigeria has become a recurring decimal, oftentimes resulting into strikes and closure of the ivory towers.

\section{Conclusion}

Information accessibility and utilization unarguably has multiplying effects on individual's positive tendencies and a key to effective learning, teaching and research delivery. The libraries provide relevant literature to academic communities for research and academic excellence. It is established through this study that although researchers found it more convenient with electronic resources but efforts to optimize utilization resulted in low productivity as a result of many challenges. This includes inadequate workstations, poor working environment, and outrageous enrolment of students above available spaces resulting into lecturers being overstretched with academic activities. Others include poor funding of libraries, epileptic power supply and computer illiteracy. All contributed to academic low productivity. Fixing-up of all the above challenges with training and re-training of lecturers on ICTs and government adequate intervention are among the remedies that would enhance job performance of university lecturers.

\section{Recommendations}

The roles that access to information and utilization play in the learning, teaching and research process in any higher institution especially the universities in Nigeria are enormous. The Federal government of Nigeria in collaboration with the university administrators should attach greater importance to teaching resources that can enhance job performance of the lecturers. Regular distribution of electricity power to campuses is very important, but as a palliative, powerful generators could be provided to keep the ICT facilities functioning when there is power failure.

Funding in any organisation/ institutions determine the success or failure of the goals and objectives of the parent organisation. It was clearly revealed that Faculties of Agricultural Sciences in the selected Universities were inadequatelyfunded; improved funding will bring about high job performance and productivity.University lecturers should also be exposed to continuous training and retraining on ICT education so that information utilization and accessibility could be friendlier to use.

\section{References}

[1] Abdullahi, Z. M., \& Haeunna, I. (2008). Public Library Boards, Information andCommunication Technology: Imposed Challenges in Adamawa State, Library Boards;. The Research Librarian Journal of the Nigerian Library Association, Abia State Chapter, 3, 19.

[2] Adebowale, T. A. (2007). Marital Conflict As Determinant of Poor Academic PerformanceAmong Some Selected Secondary Schools in Ibadan, Oyo-State, Nigeria. International Journal of Applied Psychology and Human Performance, 2, 386-394.

[3] Aina, A. (2010). A Panacea for Effective Technical Services in Nigerian Academic Libraries. International Journal of Creativity \&Technical Development, 2 (1-3): 51-60.

[4] Aina, L. O. (2004). Library and Information Science Text for Africa, Gaboron: University of Botswana, xi. 1-365.

[5] Akinyemi,S\& Bassey, O. I. (2012). Planning and Funding of Higher Education in Nigeria: The Challenges. International Journal Education Studies, 1 (4): 1-86.

[6] Amogu, U. (2010). Availability of Information and Communication Technology and Users Patronage of 
Academic Libraries in Abia State of Nigeria. in the Librarian Information Journal, Journal of the Nigerian Library Association, Akwa-Ibom State Chapter, 3 (1):28-43.

[7] Anunobi,C.V. (2013)Human Capacity Building in Nigerian University Libraries: An Imperative for Academic Reference. African Journal of Library, Archival \& Information Science, 23(1): 33-44.

[8] Ayo-Shoibare, M. (2011). Funding Strategies for Quality Education in Nigeria; The Principles of Fiscal Justice. Journal of Studies in Education, 1 (1): 14-19.

[9] Brady, E. E., \& Galbraith. (2006). Print Versus Electronic Journal Use in Three Science/Technology Discipline:The Cultural Shift Process. College and Research Libraries, 67 (4): 354-363.

[10] Bwalya, K. J. (2013). Towards ICT Mainstreaming in Zambia and Botswana: Issues and Policy. International Journal of Information Processing and Communication.(IJIPC), 1 (1): 115.

[11] Danjuma,P.(2011).Business Environment Scanning for Effective Productivity. International Journal of Business and Common Market Studies, 8 (1\&2):25-36.

[12] Edom, B. (2010). Personal Characteristics and Academic Staff Utilization of Information andCommunication Technology (ICT) in Evan Ekwerem. Nigerian Libraries, Journal of the Nigerian Library Association (43): 87-106.

[13] Ileboya, I.R. (2010). The Role of Productivity in Achieving Vision 2020. In Nigeria;. International Journal of Labour and Organizational Psychology, 4 (1\&2): 15-35.

[14] Korobili- Stella, T. I. (2014). Factors that Influence the Use of Library Resources by Faculty Members. Retrieved from http://eureka.lib.teithe.gr:8080/bitstream/handle/10184/1172/k oro_01.pdf?sequence $=1$.

[15] Kpolovie, P. J., \& Obilor, I. E. (2013). Adequacy- Inadequacy: Education Funding in Nigeria. Universal Jnr. of Education and General Studies, 2 (8):239-254.

[16] Kumar, D. D. (2011). Effect of Current Electricity Stimulation Supported Learning on the Conceptual Understanding of Elementary Secondary Teachers. Journal of Science Education and Technology, Massachusetts- USA, 20 (3): 215231.

[17] Lawal, W. O., \& Taofeek, B. (2009). Survey of Information and Communication Technology (I.C.T) Availability and use in selected private secondary school Libraries in Ibadan
Township, Oyo-State. Journal of Library Education, Media and Information Studies, 1: 86-98.

[18] Nwokedi, V. C. (2007). Impact of Internet Use on Teaching and Research Activities of The Academic Staff of Faculty of Medical Sciences, UNI JOS: A Case Study. Gateway Library Journal, 10 (1): 13-22.

[19] Ode, M.I. \& Ape,R.(2013) Developing Information Literacy Skills in Students of Nigeria Tertiary Institutions: Impetus for Information Services in the Era of Globalization. Ibadan :Waltodammy Visual Concepts. 169-185.

[20] Ofori-Dwumfuo, G. O., \& Ado, L. (2013). Utilization of Information and ICT Resources by Parliamentarians in Ghana. Current Research Journals of Social Sciences, 4 (3): 213-221.

[21] Ogundeji, V. A., Oluwatomilola, B. O., \& Olatunji, O. (2009). Internet Use and Librarian Productivity in Two University Libraries. Journal of Library, Educational Media and Information Studies, 1: 13-24

[22] Oyekunle, R. A., \& Majebi, O. V. (2013). An Evaluation of the Websites of Nigerian Universities. International Journal of Information Processing and Communication.(IJIPC)., 1: 60-72.

[23] Oyewusi, F. O., \& Oyeboade, S. A. (2009). An Empirical Study of Accessibility and Use of Library Resources by Undergraduates in a Nigerian State University of Technology.Library Philosophy and Practice. Retrived from http/www.webpages.uidaho.edu/moblin/oyewusioyeboade.htm on November 2014.

[24] Popoola, S. O. (2009). Self efficacy, Information Acquisition and Utilization as Correlates of Effective Decision Making among Managers in Insurance Companies in Nigeria. Malaysian Journal of Library and Information Science., 14 (1): 1-15.

[25] Rajput, P. S. (2010). Automation and Problems in their Implementation: An Investigation of Special Libraries, in Indore, India. International Journal of Library and Information Science, 2 (7): 143-147.

[26] Tunde, O., \& Issa,A (2013). The Quality of Nigerian Higher Education and The Funding of the Library Resources. Ozean Journal of Social Sciences, 6 (2): 1-25.

[27] Ugah, A. D. (2007). Obstacles to Information Access and Use in Developing Countries. Library Philosophy and Practice, retrieved from http://www.webpages.uidaho.edu/ mbolin/ugah3.htm on 24th November, 2014. 